\title{
Induction of Cyp450 enzymes by 4-thiazolidinone-based derivatives in 3T3-L1 cells in vitro
}

\author{
Konrad A. Szychowski ${ }^{1}$ (D) Bartosz Skóra ${ }^{1}$ (D) - Anna Kryshchyshyn-Dylevych ${ }^{2}$ (D) - Danylo Kaminskyy ${ }^{2}$ (D) \\ Kamila Rybczyńska-Tkaczyk ${ }^{3}$ (D) $\cdot$ Roman Lesyk $^{1,2}$ (D) Jan Gmiński ${ }^{1}$ (D)
}

Received: 18 September 2020 / Accepted: 15 November 2020 / Published online: 21 November 2020

(C) The Author(s) 2020

\begin{abstract}
4-Thiazolidinones and related derivatives are regarded as privileged structures in medicinal chemistry and a source of new druglike compounds. To date it is known that thiazolidinones are able to induce CYP1A1 activity in 3T3-L1 cells. Therefore, to extend the knowledge of the mechanism of thiazolidinones in the cell, four chemically synthesized heterocycles were tested on 3T3-L1 cells. The 3T3-L1 cells were exposed to Les-2194, Les-3640, Les-5935, and Les-6166. Our study showed that $1 \mu \mathrm{M}$ $\beta N F$, Les-2194, and Les-6166 decreased the expression of Ahr mRNA. In turn, $\beta N F$, Les-2194, and Les-3640 increased the Cypla1 mRNA expression at the same time interval. On the other hand, Les-5935 was found to decrease the Cypla1 mRNA expression. Interestingly, the expression of Cyp1a2 mRNA was activated only by $\beta N F$ and Les-2194. The expression of Cyp $1 b 1$ mRNA in the $3 \mathrm{~T} 3$ cell line increased after the $\beta \mathrm{NF}$ and Les-2194 treatment but declined after the exposure to Les-5935 and Les6166. Moreover, the Les-2194 and Les-5935 compounds were shown to increase the activity of EROD, MROD, and PROD. Les3640 increased the activity of EROD and decreased the activity of PROD. In turn, the treatment with Les-6166 resulted in an increase in the activity of EROD and a decrease in the activity of MROD and PROD in the 3T3-L1 cells.
\end{abstract}

Keywords CYP450 · 4-Thiazolidinone $\cdot$ Cyp1a1 · 3T3-L1 cells $\cdot$ Cyp1b1 $\cdot$ AhR

\section{Highlights}

- Les-2194, Les-3640, Les-5935, and Les-6166 do not affect cell viability in the range from $100 \mathrm{nM}$ to $1 \mu \mathrm{M}$.

- Compounds Les-3640 and Les-6166 at the 50 and $100 \mu \mathrm{M}$ concentrations activate caspase-3 in 3T3-L1 cells.

- Les-2194 increases the activity of EROD, MROD, and PROD and the Cypla 2 mRNA expression in 3T3-L1 cells.

- Les-2194 and Les-3640 increase the Cyplal mRNA expression in 3T3L1 cells.

- Les-6166 increases the activity of EROD and decreases the activity of MROD and PROD in 3T3-L1 cells.

Konrad A. Szychowski kszychowski@wsiz.edu.pl

Bartosz Skóra

bskora@wsiz.edu.pl

Anna Kryshchyshyn-Dylevych

kryshchyshyn.a@gmail.com

Danylo Kaminskyy

dankaminskyy@gmail.com

Kamila Rybczyńska-Tkaczyk

kamila.rybczynska-tkaczyk@up.lublin.pl

Roman Lesyk

rlesyk@wsiz.edu.pl
Jan Gmiński

jgminski@wsiz.edu.pl

1 Department of Lifestyle Disorders and Regenerative Medicine, University of Information Technology and Management in Rzeszow, Sucharskiego 2, 35-225 Rzeszow, Poland

2 Department of Pharmaceutical, Organic and Bioorganic Chemistry, Danylo Halytsky Lviv National Medical University, Pekarska 69, Lviv 79010, Ukraine

3 Department of Environmental Microbiology, University of Life Sciences, Leszczyńskiego 7, 20-069 Lublin, Poland 


$\begin{array}{ll}\text { Abbreviations } \\ \text { AhR } & \text { Aryl hydrocarbon receptor } \\ \text { DMSO } & \text { Dimethyl sulfoxide } \\ \text { PBS } & \text { Phosphate-buffered saline } \\ \text { PPARs } & \text { Peroxisome proliferator-activated receptors } \\ \text { ROS } & \text { Reactive oxygen species } \\ \text { XO } & \text { Xanthine oxidize } \\ \alpha \mathrm{NF} & \text { Alpha-naphthoflavone } \\ \beta N F & \text { Beta-naphthoflavone } \\ \text { EROD } & \text { Ethoxyresorufin-O-deethylase } \\ \text { MROD } & \text { 7-Methoxyresorufin O-demethylation } \\ \text { PROD } & \text { Pentoxyresorufm O-dealkylase } \\ \text { DMEM } & \text { Dulbecco's Modified Eagle's Medium }\end{array}$

\section{Introduction}

4-Thiazolidinones and related derivatives are regarded as privileged structures in medicinal chemistry and are a source of new drug-like compounds (Tripathi et al. 2014; Kaminskyy et al. 2017a). In terms of modern medicinal chemistry, 4thiazolidinones possess a variety of biological activities (both in screening campaigns and directed experiments). They are also regarded as a tool for synthesis of related heterocycles, simplified analogs, and diverse complex heterocycles in various approaches. Moreover, among the variety of thiazolidinone subtypes, 5-ene-4-thiazolidinones are of special interest as hit and lead compounds with anticancer, antimicrobial, antiviral, and antitrypanosomal activities (Kaminskyy et al. 2017a; Lesyk 2020a, b). However, a new trend in medicinal chemistry refers to these compounds as frequent hitters or pan-assay interference compounds, which are useless due to their possible low selectivity. This is challenged by the Michael acceptor property of 5-ene-4thiazolidinones (Kaminskyy et al. 2017b). Such a thesis is actively discussed in the literature and requires further investigation. Nevertheless, we established earlier that annealing of the thiazolidine core into fused analogs (thiopyrano[2,3- $d$ ] thiazoles, chromeno[2,3- $d$ ] thiazoles, thiazolo[4,5-b]pyridine, etc.) is one of the prominent optimization directions that helps to conserve the activity pattern of synthetic precursors (5-ene4-thiazolidinones), decrease the toxicity, and avoid the Michael acceptor properties as well (Kryshchyshyn et al. 2018).

To date, it has been described that 4-thiazolidinones derivates can be peroxisome proliferator-activated receptor (PPAR) agonists (Wright et al. 2014; Zhou et al. 2015; Szychowski et al. 2017a). PPARs are members of the nuclear receptor superfamily that can be activated by various natural fatty acids and xenobiotics (Berger et al. 2005; Scatena et al. 2008; Wojtowicz et al. 2014). Three subtypes of PPARs, i.e., $\operatorname{PPAR} \alpha, \operatorname{PPAR} \beta$, and PPAR $\gamma$, have been identified (Lea et al. 2004; Scatena et al. 2008; Tachibana et al. 2008).
After activation, PPARs bind with the retinoid $\mathrm{X}$ receptor (RXR) and form PPARs/RXR heterodimers, which regulate transcription of genes involved in different metabolic pathways (Bardot et al. 1993). Similarly, the aryl hydrocarbon receptor (AhR) requires participation of RXR for activation of gene expression (Hessel-Pras et al. 2018). Moreover, Wójtowicz et al. (2017) described crosstalk between AhR and PPAR $\gamma$ receptors in mouse neurons. Similarly, as reported by Kim et al. (2008), troglitazone (PPAR $\gamma$ agonist) affects induction of Cyp1a1, whose expression is AhR dependent, in murine hepatoma Hepa-1c1c7 cells. It has also been described that alpha-naphthoflavone $(\alpha \mathrm{NF})$, which is an AhR antagonist, inhibits differentiation of 3T3-L1 pre-adipocytes, which is a well-documented PPAR $\gamma$-dependent process (He et al. 2013). To date, PPAR $\gamma$ activators have been reported to act as carcinogens as well, as described in some papers (Scatena et al. 2008).

It is well known that many xenobiotics can accumulate in adipose tissue (Barouki 2013). Unfortunately, the consequences of this accumulation are still poorly understood (Jackson et al. 2017). Moreover, adipose tissue can also metabolize xenobiotics to a small extent with the involvement of cytochrome P450 enzymes (Ellero et al. 2010), e.g., CYP1A1, which has been examined extensively for its capacity to activate compounds with carcinogenic properties (Androutsopoulos et al. 2009). Exposure to chemicals and environmental carcinogens is thought to increase the level of CYP1A1 expression in extrahepatic tissues through the AhR receptor (Nebert et al. 2000; Di Bello et al. 2007). Dysregulation of these pathways may be implicated in tumor progression (Androutsopoulos et al. 2009). Similarly CYP1B1, which is expressed in liver and extrahepatic tissues, carries out the metabolism of numerous xenobiotics, including the metabolic activation of polycyclic aromatic hydrocarbons (Spink et al. 1998). Moreover, CYP1B1 has also been shown to be important in regulating endogenous metabolic pathways, including the metabolism of steroid hormones, fatty acids, melatonin, and vitamins ( $\mathrm{Li}$ et al. 2017). CYP1B1 and its interaction with PPARs, estrogen receptors (ERs), and retinoic acid receptors (RARs) contribute to the maintenance of the homeostasis of these endogenous compounds (Angus et al. 1999; Nebert and Dalton 2006). Accumulating data indicate that modulation of CYP1B1 can decrease adipogenesis and tumorigenesis and prevent obesity, hypertension, atherosclerosis, and cancer (Malik et al. 2012; Song et al. 2016; Li et al. 2017). Therefore, it may be feasible to consider CYP1B1 as a therapeutic target for the treatment of metabolic diseases ( $\mathrm{Li}$ et al. 2017; Alzahrani and Rajendran 2020).

The molecular mode of the anticancer action of the abovementioned compounds is still unclear, but it is believed to be related with PPAR pathways (Lu et al. 2011; Asati et al. 2014). Our previous study has demonstrated that 4thiazolidinone-based derivatives (thiopyrano[2,3- $d]$ thiazole 
derivative Les-2194 and thiazolidinone-pyrazoline hybrid molecule Les-3640) cause apoptotic cell death in human squamous carcinoma cells (SCC-15) with key involvement of PPAR $\gamma$ (Szychowski et al. 2017a, b). Moreover, another compound studied by our team 5Z-(4-fluorobenzylidene)-2-(4hydroxyphenylamino)-thiazol-4-one (Les-236) has been found to exhibit broad cytotoxic and proapoptotic action in SCC-15, lung carcinoma (A549), colon adenocarcinoma (CACO-2), neuroblastoma (SH-SY5Y), and skin fibroblast (BJ) cell lines (Szychowski et al. 2019).

At present, there are very limited data on the influence of anticancer 4-thiazolidinone-based derivatives on Cyp1a1, Cyp1b1, Cyp1a2, and Cyp2b10 expression or activity. Moreover, the impact of Les-2194, Les-3640, Les-5935 (chromeno[2,3-d]thiazole derivative), or Les-6166 (thiazolidinone-indole hybrid) on induction of Cyp1a1, Cyp1b1, Cyp1a2, and Cyp2b10 expression or activity has never been studied. These compounds represent the most promising classes of 4-thiazolidinone-based derivatives as potential anticancer agents. In particular, Les-2194 (Havrylyuk et al. 2012), Les-3640 (Kryshchyshyn et al. 2012), and Les5935 (Table S1, ESI) inhibited the growth of sixty cancer cell lines representing nine neoplastic diseases at sub-micromolar and micromolar concentrations according to US NCI protocols (Shoemaker 2006).

Due to the lipophilic nature of the studied compounds, the mouse non-cancerous preadipocyte 3T3-L1 cell line was selected for metabolism studies. In addition, it is possible that they accumulate in adipose tissue. Therefore, the aim of our study was to determine whether the 4-thiazolidinone-based derivatives induce the expression and/or activity of Cyplal, Cyp1b1, Cyp1a2, and Cyp2b10 in the 3T3-L1 cell line.

\section{Materials and methods}

\section{Reagents}

Dulbecco's Modified Eagle's Medium (DMEM) without phenol red (10-013CV) and phosphate-buffered saline without calcium and magnesium (PBS) (21-040-CVR) were purchased from Corning (Manassas, VA, USA). Trypsin, penicillin, streptomycin, amphotericin $\mathrm{B}, \beta$-naphthoflavone ( $\beta N F)$ (N3633), and dimethyl sulfoxide (DMSO) were purchased from Sigma-Aldrich (St. Louis, MO, USA). Substrates for P450 cytochrome ethoxyresorufin-O-deethylase (EROD) (5725-91-7), 7-methoxyresorufin O-demethylation (MROD) (5725-89-3), and pentoxyresorufm O-dealkylase (PROD) (87687-03-04) were supplied by Tocris Bioscience. Fetal bovine serum (FBS) (E5050-02), RNA isolation kits (E0309), and fast probe qPCR master mix (Rox) (E0423) were purchased from EURx (Gdańsk, Poland). TaqMan probes corresponding to specific genes encoding Gapdh
(Mm99999915_g1), Ahr (Mm01291777_m1), Cyplal (Mm00487218 m1), Cyp1b1 (Mm00487229 m1), Cypla2 (Mm00487224_m1), and Cyp2b10 (Mm01972453_s1) were purchased from Thermo Fisher Scientific (Grand Island, NY, USA).

Synthesis and physicochemical data of the tested compounds were described previously: Les-2194, rel-N-(2,4dichlorophenyl)-2-[(5aR,11bR)-2-oxo-5a,11b-dihydro$2 H, 5 H$-chromeno[4', $\left.3^{\prime}: 4,5\right]$ thiopyrano[2,3- $\left.d\right][1,3]$ thiazol$3(6 H)$-yl]acetamide (Kryshchyshyn et al. 2012), and Les3640, 3-\{2-[5-(4-dimethylaminophenyl)-3-phenyl-4,5dihydropyrazol-1-yl]-4-oxo-4,5-dihydro-1,3-thiazol-5-ylidene\}-2,3-dihydro- $1 H$-indol-2-one (Havrylyuk et al. 2012). Spectral and analytical data for Les-5935 (9Hbenzo[5,6]chromeno[2,3- $d][1,3]$ thiazol-9-one) and Les-6166 (methyl 5-fluoro-3-[2-(4-hydroxyanilino)-4-oxo-4,5-dihydro1,3-thiazol-5-ylidenmethyl]-1 $H$-2-indolecarboxylate) are described in the Supplementary information.

All stock solutions were prepared by dissolving the compounds in DMSO. The final concentration of DMSO in the culture medium was always $0.1 \%$.

\section{Synthesis of anticancer 4-thiazolidinone-based derivatives}

The synthesis of Les-2194 and Les-3166 was performed according to the method described by Kryshchyshyn et al. (2012) and Havrylyuk et al. (2012), respectively.

\section{General procedure for the synthesis of $9 \mathrm{H}$-benzo[ $[5,6]$ chromeno[2,3-d][1,3]thiazol-9-one (Les-5935)}

Mixtures of 4-aminothiazol-2(5H)-one (5 mmol), 2hydroxynaphthalene-1-carbaldehyde (5 mmol), and sodium acetate $(5 \mathrm{mmol})$ were heated at reflux for $2 \mathrm{~h}$ in a mixture of $\mathrm{AcOH}$ and $\mathrm{Ac}_{2} \mathrm{O}(10 \mathrm{~mL}, 1: 1)$. After cooling, the precipitate formed was filtered off, washed with $\mathrm{AcOH}, \mathrm{H}_{2} \mathrm{O}$, and $\mathrm{EtOH}$, and recrystallized from a mixture of DMF/EtOH (2:1). Spectral and analytical data for compound Les-5935 is provided in supplementary material 1 .

\section{General procedure for the synthesis of methyl 5-fluoro-3-[2-(4-hydroxyanilino) -4-oxo-4,5-dihydro-1,3-thiazol-5-ylidenmethyl] -1H-2-indolecarboxylate (Les-6166)}

A mixture of 0.1 mole of 4-hydroxyphenylthiourea $(0.1 \mathrm{~mol})$, methyl 5-fluoro-3-formylindole-2-carboxylate $(0.11 \mathrm{~mol})$, chloroacetic acid $(0.1 \mathrm{~mol})$, and fused sodium acetate $(0.1$ $\mathrm{mol}$ ) in $100 \mathrm{~mL}$ of acetic acid was heated under reflux for 3 $\mathrm{h}$. The crystalline precipitate was filtered off, washed with acetic acid, water, ethanol, and diethyl ether, and then recrystallized from a mixture DMF-acetic acid (1:2). Spectral and 
analytical data for compound Les-6166 is provided in supplementary material 1 .

\section{T3-L1 cell culture}

Mouse embryonic fibroblast cell line 3T3-L1 was obtained from the American Type Culture Collection (ATCC, distributor: LGC Standards, Łomianki, Poland). The 3T3-L1 cell line was maintained in phenol red-free DMEM supplemented with $10 \% \mathrm{FBS}, 100 \mathrm{U} / \mathrm{mL}$ penicillin, $0.10 \mathrm{mg} / \mathrm{mL}$ streptomycin, and $250 \mathrm{ng} / \mathrm{mL}$ amphotericin B. The cells were maintained at $37{ }^{\circ} \mathrm{C}$ in a humidified atmosphere with $5 \% \mathrm{CO}_{2}$. They were seeded in 96-well culture plates at a density of 6 $\times 10^{3}$ (for the 24 -h treatment), $5 \times 10^{3}$ (for the 48 -h treatment), and $4 \times 10^{3}$ (for the 72 -h treatment) per well and initially cultured before the experiment for $24 \mathrm{~h}$. Subsequently, the medium was replaced with a fresh one by raising the concentrations $(100 \mathrm{nM}, 1 \mu \mathrm{M}, 10 \mu \mathrm{M}, 50 \mu \mathrm{M}$, and $100 \mu \mathrm{M})$ of Les2194, Les-3640, Les-5935, and Les-6166 (resazurin reduction and caspase- 3 activity).

\section{Resazurin reduction assay}

The resazurin reduction assay was used to determine the rate of cell metabolism and, based on this, cell viability (Rampersad 2012). Resazurin is a redox dye showing colorimetric and fluorometric changes depending on the cell metabolic activity. The resazurin reduction assay is based on the ability of metabolically active cells to convert blue resazurin (non-fluorescent form) to red resorufin (fluorescent form). To determine viability, the cells were seeded in 96-well plates. They were incubated in different series of the Les-2194, Les3640, Les-5935, and Les-6166 compounds (100 nM, $1 \mu \mathrm{M}$, $10 \mu \mathrm{M}, 50 \mu \mathrm{M}$, and $100 \mu \mathrm{M}$ ) for $24 \mathrm{~h}, 48 \mathrm{~h}$, and $72 \mathrm{~h}$ at $37^{\circ} \mathrm{C}$. Next, the dilutions of the compounds were removed, and the DMEM medium containing $1 \%$ FBS and $10 \%$ of resazurin was added. Then, after 30 and $60 \mathrm{~min}$ of incubation, fluorescence measurements were made using a microplate reader (FilterMax F5). The maximum excitation spectrum was 530 $\mathrm{nm}$, and the emission was $590 \mathrm{~nm}$. The data were analyzed using Multi-Mode Analysis software and normalized to the fluorescence in the vehicle-treated control (\% of control).

\section{Caspase-3 activity}

Caspase-3 activity was used as a marker of cell apoptosis and was assessed according to Nicholson et al. (1995). To measure caspase-3 activity, the cells were seeded on 96-well plates and exposed to Les-2194, Les-3640, Les-5935, and Les-6166. After thawing $\left(-80^{\circ} \mathrm{C}\right)$, the cells were lysed using lysis buffer (50 mM HEPES, pH 7.4, $100 \mathrm{mM} \mathrm{NaCl,} \mathrm{0.1 \%} \mathrm{CHAPS,}$ $1 \mathrm{mM}$ EDTA, $10 \%$ glycerol, and $10 \mathrm{mM} \mathrm{DTT}$ ) at $10{ }^{\circ} \mathrm{C}$ for $10 \mathrm{~min}$. The lysates were incubated in the caspase- 3 substrate
Ac-DEVD-pNA at $37{ }^{\circ} \mathrm{C}$. Cells treated with $1 \mu \mathrm{M}$ staurosporine were used as a positive control (data not shown). After $30 \mathrm{~min}$, the absorbance of the lysates at $405 \mathrm{~nm}$ was measured using a microplate reader (FilterMax F5). The amount of the colorimetric product was continuously monitored for $120 \mathrm{~min}$. The data were analyzed using MultiMode Analysis software and normalized to the absorbance in the vehicle-treated cells.

\section{qPCR analysis of mRNAs specific to genes encoding Ahr, Cyp1a1, Cyp1b1, Cyp1a2, and Cyp2b10}

The quantitative polymerase chain reaction (qPCR) method was chosen to determine whether the tested compounds increase gene expression. The experiment was conducted with a procedure described previously (Szychowski et al. 2017a). For the qPCR assay, 3T3-L1 cells were seeded onto 12-well plates and initially cultured for $24 \mathrm{~h}$. After 6-h exposure to $1 \mu \mathrm{M} \beta \mathrm{NF}$, Les-2194, Les-3640, Les-5935, or Les-6166, the samples were collected, and total RNA was extracted from the 3T3-L1 cells using a RNA isolation kit (EURx, Gdańsk, Polska) according to the manufacturer's instructions. Both the quality and quantity of the RNA were determined spectrophotometrically at 260 and $280 \mathrm{~nm}$, respectively (ND/1000 UV/Vis; Thermo Fisher NanoDrop, USA). Two-step realtime reverse transcription (RT)-PCR was conducted with both the $\mathrm{RT}$ reaction and the quantitative PCR (qPCR) run using the CFX real-time system (Bio-Rad, USA). The RT reaction was carried out at a final volume of $20 \mu \mathrm{L}$ with $800 \mathrm{ng}$ RNA (as a cDNA template) using the cDNA reverse transcription kit in accordance with the manufacturer's instructions. Products of the RT reaction were amplified using the fast probe qPCR master mix (EURx) with TaqMan probes as primers for specific genes encoding Gapdh, Ahr, Cyplal, Cyp1b1, Cyp1a2, and Cyp2b10. The amplification was carried out in a total volume of $20 \mu \mathrm{L}$ containing $1 \times$ fast probe qPCR master mix (EURs) and $1.0 \mu \mathrm{L}$ of the RT product, which was used as the PCR template. The standard qPCR procedures were carried out as follows: $2 \mathrm{~min}$ at $50{ }^{\circ} \mathrm{C}$ and $10 \mathrm{~min}$ at $95^{\circ} \mathrm{C}$, followed by 45 cycles of $15 \mathrm{~s}$ at $95^{\circ} \mathrm{C}$ and $1 \mathrm{~min}$ at $60^{\circ} \mathrm{C}$. The threshold value $(\mathrm{Ct})$ for each sample was set during the exponential phase, and the $\Delta \Delta \mathrm{Ct}$ method was used for data analysis. Gapdh was used as the reference gene.

\section{CYP450 activities (EROD, MROD, and PROD assays)}

To confirm the results of the qPCR reaction and their translation into functional protein, the activity of the studied cytochromes was tested. We estimated the activity of the Cypla1/ Cyp1b1, Cyp1a2, and Cyp2b1 enzymes using the fluorometric ethoxyresorufin-O-deethylase (EROD), 7 methoxyresorufin O-demethylation (MROD), and pentoxyresorufm O-dealkylase (PROD) substrates, 
respectively. The fluorescence EROD, MROD, and PROD assays were performed according to the method proposed by Kennedy et al. (1993). For the assays, the cells were seeded on 12-well plates and initially cultured for $24 \mathrm{~h}$. Measurement of the EROD, MROD, and PROD activity was performed after 24 or $48 \mathrm{~h}$ of exposure to $1 \mu \mathrm{M} \beta \mathrm{NF}$, Les-2194, Les-3640, Les5935, and Les-6166. To perform the EROD, MROD, and PROD assays, lysed cells were transferred into multiwell plates, and the fluorescent product resorufin was quantified within the wells with a fluorescence plate reader (FilterMax F5) at an excitation wavelength of $530 \mathrm{~nm}$ and an emission wavelength of $590 \mathrm{~nm}$. The protein concentration was determined spectrophotometrically in triplicate for each sample at $280 \mathrm{~nm}$ using the ND/1000 UV/Vis Thermo Fisher NanoDrop device.

\section{Statistical analysis}

The data are presented as means $\pm \mathrm{SD}$ of three independent experiments. Each treatment was repeated six times in each independent experiment $(n=18)$. The data were analyzed with one-way analysis of variance (ANOVA) followed by Tukey's multiple comparison procedure $* * * P<0.001, * * P<0.01$, and $* P<0.05$ vs. the control.

\section{Results}

\section{Synthesis of 4-thiazolidinone-based derivatives}

The general methods for the synthesis of the target thiazolidinone-based compounds Les-2194, Les-3640, Les5935, and Les-6166 are presented in Fig. 1. Les-2194 was obtained via $N$-alkylation of rel-(5aR,11bR)-3,5a,6,11btetrahydro- $2 H, 5 H$-chromeno[ $\left[4^{\prime}, 3^{\prime}: 4,5\right]$ thiopyrano[2,3d] thiazol-2-one by 2-chloro- $N$-(3,4-dichlorophenyl)-acetamide. Les-3640 and Les-6166 were synthesized in a one-pot threecomponent reaction involving [2+3]-cyclocondensation of appropriate $S, N$-binucleophile and chloroacetic acid followed by the Knoevenagel reaction with an appropriate oxo compound. In the case of Les-3640, 3-phenyl-5-(dimethylaminophenyl)-1thiocarbamoyl-2-pyrazoline was used as the $S, N$-binucleophile, and isatin was used as the oxo compound; for the Les-6166 synthesis, 4-hydroxyphenylthiourea and methyl 5-fluoro-3formylindole-2-carboxylate were used, respectively. The chromeno[2,3-d] thiazole Les-5935 was obtained via one-pot condensation of 4-aminothiazol-2(5H)-one and 2hydroxynaphthalene-1-carbaldehyde.

\section{Measurement of resazurin reduction}

Several thiazolidinone-based compounds have been previously shown to impact the viability of tumor cells (Szychowski et al. 2017a,b, 2019). Resazurin reduction experiments were performed to measure the effects of Les-2194, Les-3640, Les5935 , and Les-6166 on the viability of 3T3-L1 preadipocytes.

After the 24-h exposure to $100 \mathrm{nM}, 1 \mu \mathrm{M}, 10 \mu \mathrm{M}, 50 \mu \mathrm{M}$, and $100 \mu \mathrm{M}$ of Les-2194, Les-3640, Les-5935, or Les-6166, only $100 \mu \mathrm{M}$ of Les-2194 and Les-3640 induced a decrease in resazurin reduction in the 3T3-L1 cells (a decrease by 16.43 and $15.77 \%$, respectively, compared to the control) (Fig. 2a).

Similarly, after the 48-h exposure to $100 \mathrm{nM}, 1 \mu \mathrm{M}, 10 \mu \mathrm{M}$, $50 \mu \mathrm{M}$, and $100 \mu \mathrm{M}$ of Les-2194, Les-3640, Les-5935, or Les6166, $100 \mu \mathrm{M}$ of Les-2194 and Les-3640 caused a decrease in resazurin reduction in the 3T3-L1 cells (a decrease by 17.07 and $24.83 \%$ respectively, compared to the control). Moreover, Les6166 decreased resazurin reduction at the concentrations of $50 \mu \mathrm{M}$ and $100 \mu \mathrm{M}$ (a decrease by 16.44 and $28.19 \%$, respectively, compared to the control). In turn, compound Les-5935 at the concentration of $100 \mu \mathrm{M}$ increased resazurin reduction by $14.19 \%$, compared to the control (Fig. 2b).

After the 72-h exposure to the studied compounds, or Les6166, similar as in the previous variant, $100 \mu \mathrm{M}$ of Les-2194 and Les-3640 contributed to a decrease in resazurin reduction in the 3T3-L1 cells (a decrease by 17.88 and $13.20 \%$, respectively, compared to the control). Les-6166 decreased resazurin reduction at the concentrations of $10 \mu \mathrm{M}, 50 \mu \mathrm{M}$, and $100 \mu \mathrm{M}$ (a decrease by $16.15,28.77$, and $26.65 \%$, respectively, compared to the control). In turn, compound Les-5935 at the concentration of $10 \mu \mathrm{M}, 50 \mu \mathrm{M}$, and $100 \mu \mathrm{M}$ increased resazurin reduction by $13.12,11.68$, and $11.75 \%$, respectively, compared to the control (Fig. 2c).

\section{Measurement of caspase- 3 activity}

To date, thiazolidinone-based compounds have been shown to initiate the apoptotic process in various cancerous cell lines (Szychowski et al. 2017a,b, 2019). Caspase-3 activity assay was performed to measure the effects of Les-2194, Les-3640, Les-5935, and Les-6166 on the apoptotic process in the 3T3L1 cell line.

After the 24-h exposure to $100 \mathrm{nM}, 1 \mu \mathrm{M}, 10 \mu \mathrm{M}, 50 \mu \mathrm{M}$, and $100 \mu \mathrm{M}$ of Les-2194, Les-3640, Les-5935, or Les-6166, compounds Les-2194 and Les-5935 did not affect caspase-3 activity in the 3T3-L1 cells. Compounds Les-3640 and Les6166 at the concentrations of $50 \mu \mathrm{M}$ and $100 \mu \mathrm{M}$ caused an increase in caspase- 3 activity (an increase by 44.27 and 79.75\%, respectively, for Les-3640 and an increase by 95.09 and $147.44 \%$, respectively, for Les-6166) (Fig. 3a).

After the 48-h exposure to the studied compounds, as in the case of the 24-h exposure, compounds Les-2194 and Les5935 did not affect caspase-3 activity in the 3T3-L1 cells. Moreover, compounds Les-3640 and Les-6166 at the concentrations of $50 \mu \mathrm{M}$ and $100 \mu \mathrm{M}$ induced an increase in caspase3 activity (an increase by 40.33 and $82.33 \%$, respectively, for Les-3640 and an increase by 98.26 and $151.47 \%$, respectively, for Les-6166) (Fig. 3b). 
Fig. 1 Synthesis of target thiazolidinone-based compounds. Les-2194 is described in Kryshchyshyn et al. (2012), and Les-3640 is described in Havrylyuk et al. (2012)

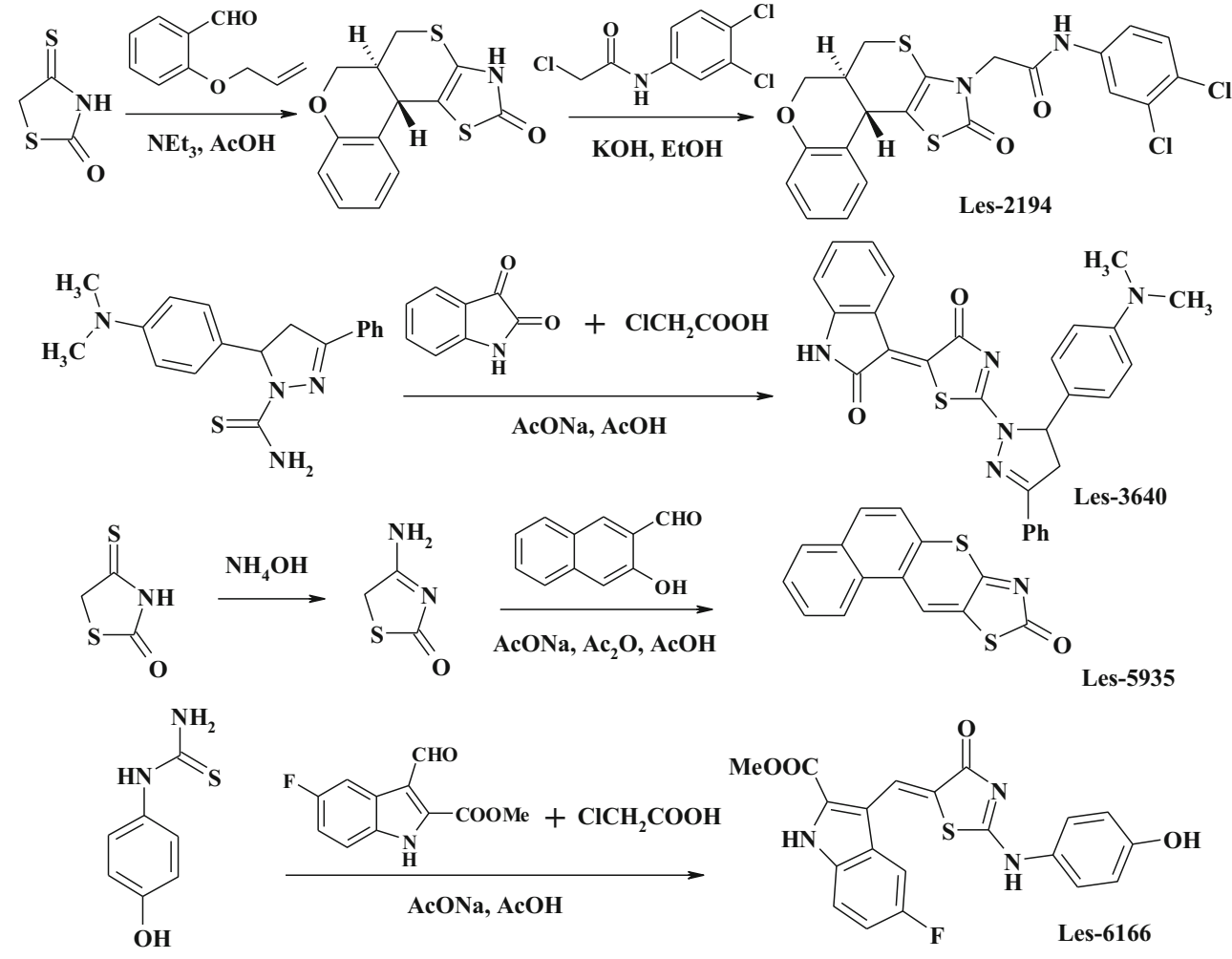

Similarly, after the 72-h exposure to the studied compounds, Les-2194 and Les-5935 did not affect caspase-3 activity in the 3T3-L1 cells. Compound Les-6166 at the concentrations of $50 \mu \mathrm{M}$ and $100 \mu \mathrm{M}$ increased caspase-3 activity (an increase by 90.85 and $163.21 \%$, respectively, compared to the control). Compound Les-3640 caused an increase in caspase-3 activity at the concentrations of $10 \mu \mathrm{M}, 50 \mu \mathrm{M}$, and $100 \mu \mathrm{M}$ (an increase by $16.18 ; 47.36$ and $85.06 \%$, respectively, compared to the control) (Fig. 3c).

\section{Expression of Ahr, Cyp1a1, Cyp1b1, Cyp1a2, and Cyp2b10 mRNA}

$\mathrm{AhR}$ and AhR-related genes are involved in the metabolism and detoxification system of different ligands, such as drugs, tetrachlorodibenzo-p-dioxin (TCDD), or $\beta N F$ (Tian et al. 2015). To date, the Les-2194 and Les-3640 compounds have been shown to exhibit properties of PPAR $\gamma$ receptor agonists (Szychowski et al. 2017a, b). Therefore, due to crosstalk between AhR and PPAR $\gamma$ receptors, investigations of the mRNA expression of $A h r$ and $A h r$-related genes were performed.

The expression of Ahr, Cyp1a1, Cyp1b1, Cyp1a2, and Cyp2b10 mRNA was measured after $6 \mathrm{~h}$ of exposure to $\beta N F$, Les-2194, Les-3640, Les-5935, or Les-6166. $\beta N F$, Les-2194, and Les-6166 were found to decrease the expression of $A h r$ mRNA by $57.97,17.00$, and $25.69 \%$ respectively, compared to the control (Fig. 4a). At the same time interval, $\beta$ NF, Les-2194, and Les-3640 increased the Cypla1 mRNA expression by $1240051.71,1325.58$, and $106.18 \%$, respectively, compared to the control. In turn, Les-5935 decreased the Cyplal mRNA expression by $56.16 \%$, compared to the control (Fig. 4b). Interestingly, the expression of Cyp 1 a 2 mRNA was activated only by $\beta$ NF and Les-2194 (41.22\% compared to the expression induced by $\beta \mathrm{NF}$ ); therefore, $\beta N F$ was regarded to be the control in this analysis (Fig. $4 \mathrm{c})$. After the $\beta \mathrm{NF}$ and Les- 2194 treatment, the expression of Cyp1b1 mRNA in the 3T3 cell line increased by 105.11 and $33.04 \%$, respectively, compared to the control. In turn, Les-5935 and Les-6166 decreased the expression of Cyp1b1 mRNA by 23.66 and $27.02 \%$, respectively, compared to the control (Fig. 4d). No expression of Cyp2b10 mRNA was detected in the $3 \mathrm{~T} 3$ cell line (Fig. 4e).

\section{CYP450 activities}

Currently, it is well known that mRNA expression does not fully translate into its functions (Perl et al. 2017). Therefore, enzymatic activity assays EROD, MROD, and PROD were carried out to confirm or deny that changes in mRNA expression affect protein activity.

\section{EROD assay}

After 24 and $48 \mathrm{~h}$ of exposure of the 3T3-L1 cells to $1 \mu \mathrm{M}$ Les-2194, Les-5935, or Les-6166, we observed an increase in 
Fig. 2 Effect of $100 \mathrm{nM}, 1 \mu \mathrm{M}$, $10 \mu \mathrm{M}, 50 \mu \mathrm{M}$, or $100 \mu \mathrm{M}$ of Les-2194, Les-3640, Les-5935, or Les-6166 on resazurin reduction after $24 \mathrm{~h}$ (a), $48 \mathrm{~h}$ (b), and $72 \mathrm{~h}(\mathbf{c})$ of exposure of 3T3-L1 fibroblasts. Control vehicle only and $1 \mu \mathrm{M} \beta$-naphthoflavone $(\beta N F)$ were included in the experiments. Data are expressed as means $\pm \mathrm{SD}$ of three independent experiments, each of which consisted of six replicates per treatment group
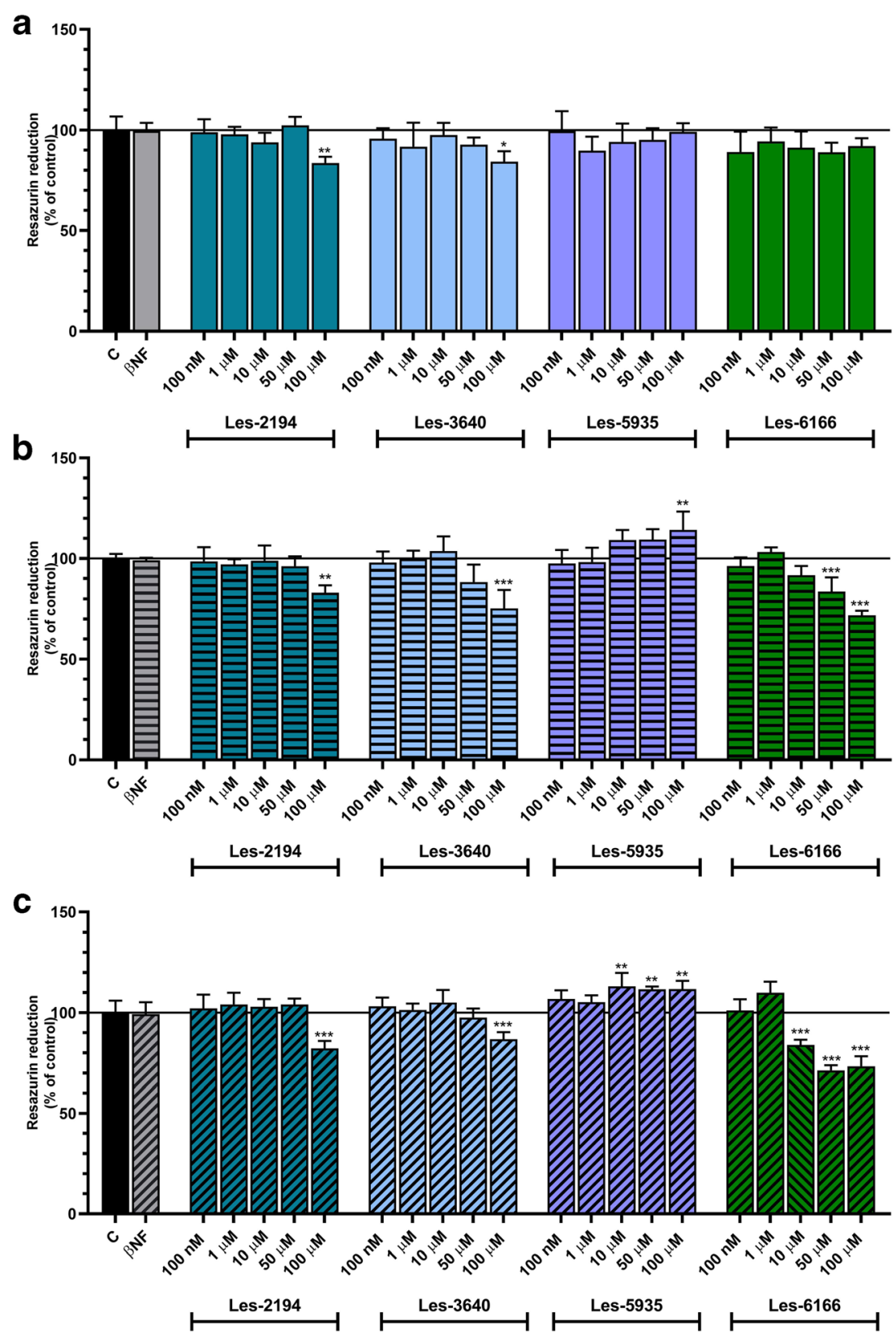

EROD activity. An increase by 76.45 and $102.90 \%$ compared to the control was observed in the case of Les-2194. Les-5935 increased the activity by 84.31 and $83.90 \%$, compared to the control, whereas an 81.29 and $74.30 \%$ increase was induced by Les-6166, compared to control. In turn, Les-3640 increased the EROD activity only after $48 \mathrm{~h}$ (by $35.40 \%$ compared to the control) (Fig. 5a).

\section{PROD assay}

After 24 and $48 \mathrm{~h}$ of exposure of the 3T3-L1 cells to $1 \mu \mathrm{M}$ Les-2194, the PROD activity was increased by 61.70 and $67.67 \%$, respectively, compared to the control. After $24 \mathrm{~h}$ of exposure to Les-3640, we observed an $18.70 \%$ decrease in the
PROD activity, compared to the control. After 48 h, Les-5935 increased the PROD activity by $61.95 \%$, compared to the control. Les-6266 induced a decrease in the PROD activity at both time intervals (a decrease by 36.00 and $38.43 \%$, compared to the control) (Fig. 5b).

\section{MROD assay}

$\beta \mathrm{NF}$ reduced the MROD activity only after $48 \mathrm{~h}$ of exposure (a decrease by $24.89 \%$, compared to the control). Likewise previously, Les-2194 increased the MROD activity in the 3T3-L1 cells after 24 and $48 \mathrm{~h}$ (an increase by 22.76 and $37.98 \%$, respectively, compared to the control). After 24-h exposure, Les-5935 increased the MROD activity by 
Fig. 3 Effect of $100 \mathrm{nM}, 1 \mu \mathrm{M}$, $10 \mu \mathrm{M}, 50 \mu \mathrm{M}$, or $100 \mu \mathrm{M}$ of Les-2194, Les-3640, Les-5935, or Les-6166 on caspase-3 activity after $24 \mathrm{~h} \mathrm{(a),} 48 \mathrm{~h}(\mathbf{b})$, and $72 \mathrm{~h}$ (c) of exposure of 3T3-L1 fibroblasts (a). Control vehicle only and $1 \mu \mathrm{M} \beta$-naphthoflavone $(\beta N F)$ were included in the experiments. Data are expressed as means \pm SD of three independent experiments, each of which consisted of six replicates per treatment group
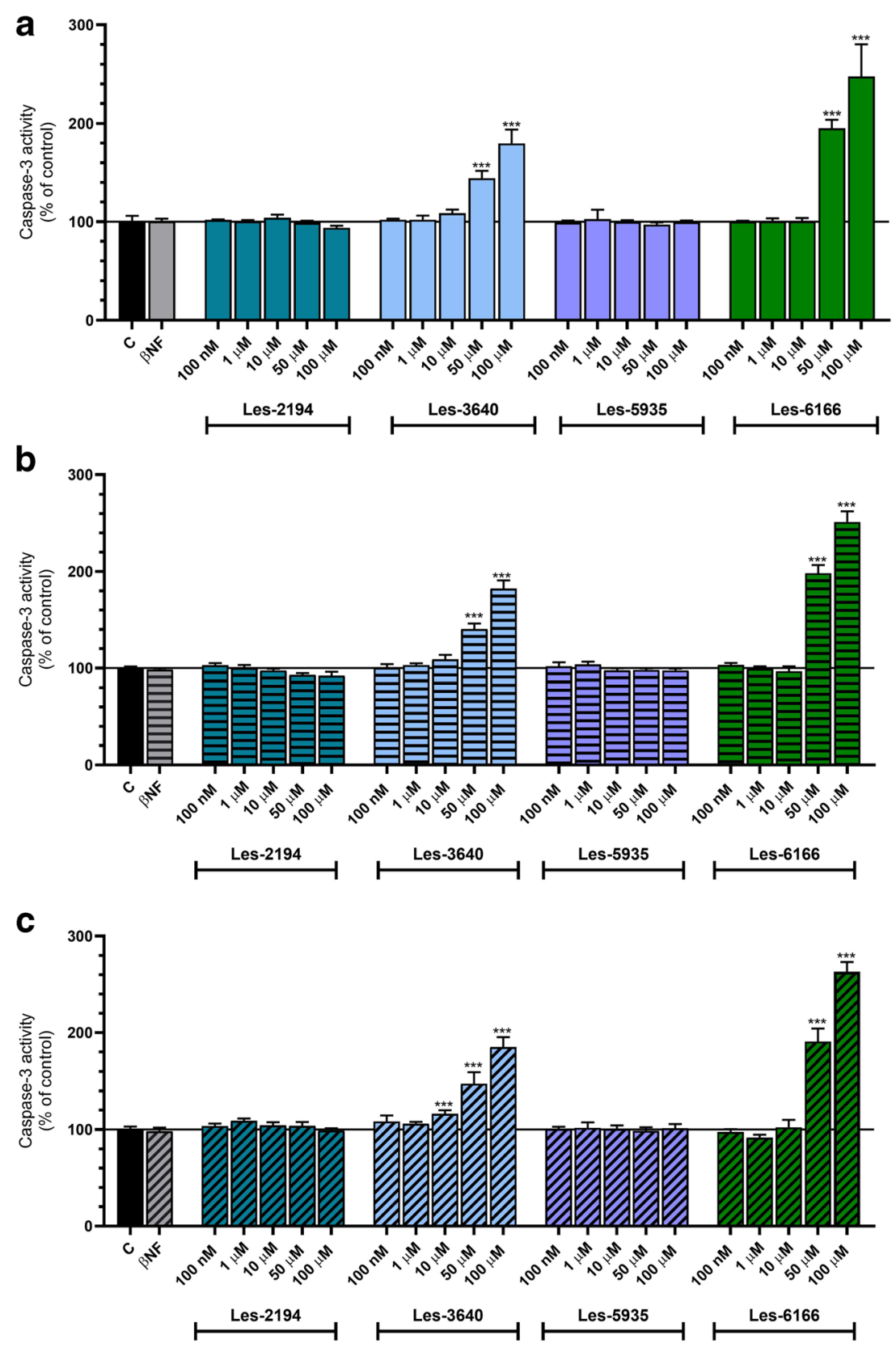

$34.64 \%$, compared to the control. In turn, Les-3640 and Les6166 contributed to a decrease in the MROD activity at both time intervals, i.e., by 34.10 and $23.55 \%$ in the case of Les3640 and by 36.02 and $32.83 \%$ in the case of Les-6166, compared to the control (Fig. 5c).

\section{Discussion}

The present experiments showed that, after 24, 48, and $72 \mathrm{~h}$ of exposure to $100 \mathrm{nM}, 1 \mu \mathrm{M}, 10 \mu \mathrm{M}, 50 \mu \mathrm{M}$, and $100 \mu \mathrm{M}$, the Les-2194, Les-3640, and Les-6166 compounds caused a significant decrease in the resazurin reduction assay only at the highest micromolar concentrations in the 3T3-L1 cells. Interestingly, compound Les-5935 after $72 \mathrm{~h}$ of exposure in the concentration range from 10 to $100 \mu \mathrm{M}$ induced an increase in the resazurin reduction assay. Moreover, at all the time intervals studied, compounds Les-2194 and Les-5935 did not affect caspase-3 activity in the 3T3-L1 cells. However, compounds Les-3640 and Les-6166 at the concentrations of $50 \mu \mathrm{M}$ and $100 \mu \mathrm{M}$ contributed to an increase in caspase- 3 activity. Therefore, it can be assumed that the compounds applied in the range $100 \mathrm{nM}$ to $1 \mu \mathrm{M}$ neither are toxic nor initiate apoptosis in the normal mouse fibroblast 3T3-L1 cell line. Our previous studies show that Les-2194 and Les3640 increased reactive oxygen species (ROS) production in 

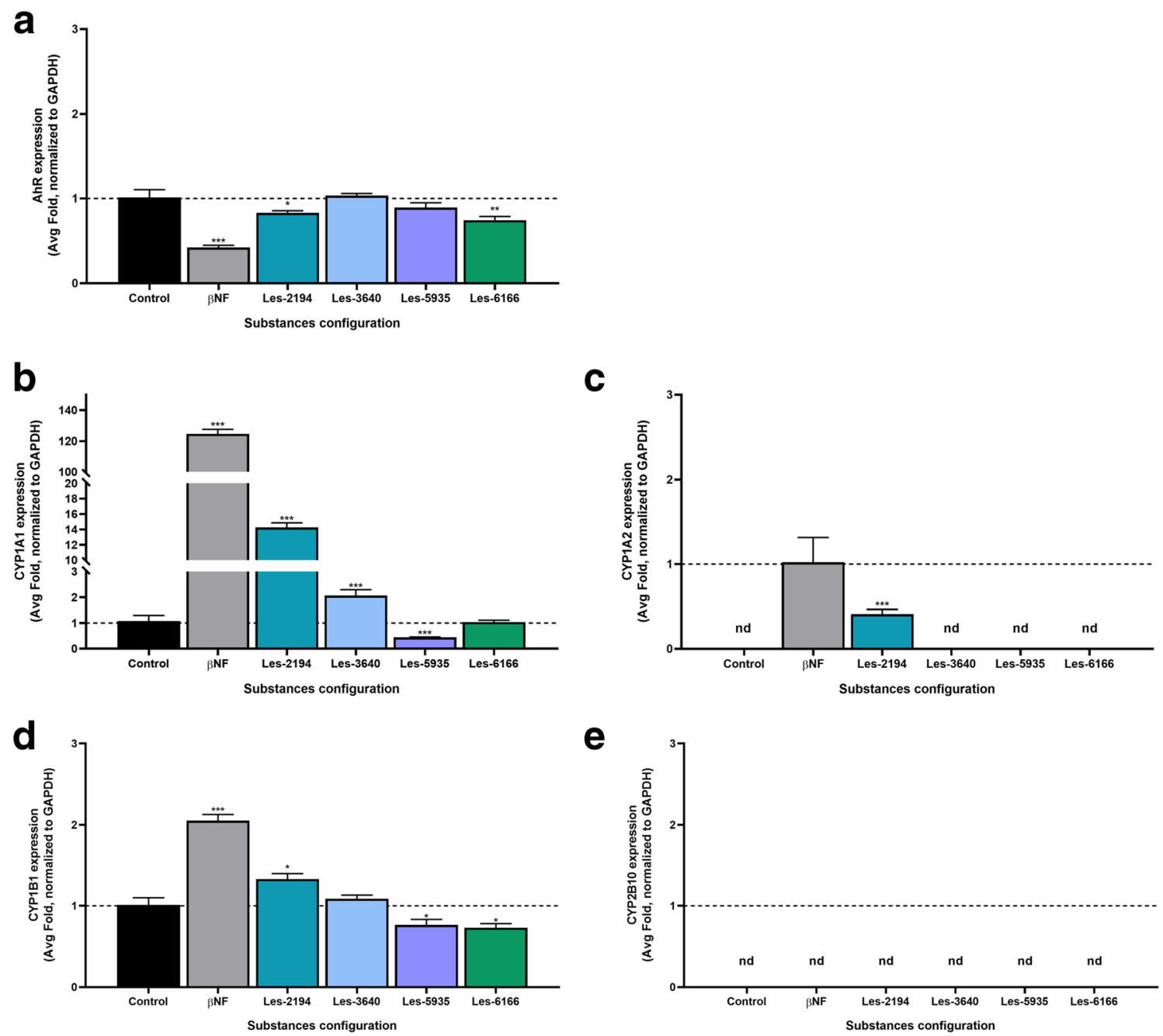

e

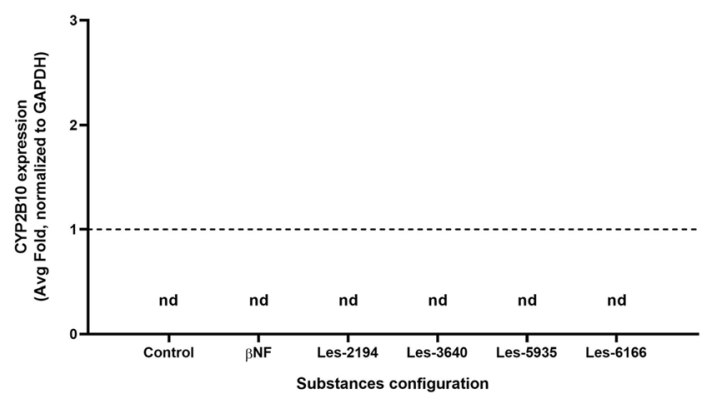

Fig. 4 Effect of $1 \mu \mathrm{M}$ Les-2194, Les-3640, Les-5935, or Les-6166 and $1 \mu \mathrm{M} \beta$-naphthoflavone ( $\beta \mathrm{NF}$ ) on the mRNA expression of $A h r$ (a), Cypla1 (b), Cypla2 (c), Cyp1b1 (d), and Cyp2b10 (e) genes after $6 \mathrm{~h}$ of exposure of 3T3-L1 fibroblasts. The lack of expression of Cyp2b10 mRNA was confirmed by the use of mouse astrocyte cells as a positive

the SCC-15 cell line. Furthermore, both Les-2194 and Les3640 decrease cell viability (measured by the resazurin reduction assay) and increase cell apoptosis (measured as caspase-3 activity) (Szychowski et al. 2017b). Moreover, our study shows that both Les-2194 and Les-3640 act in a PPAR $\gamma$ dependent way (Szychowski et al. 2017a). Resveratrol, which is known as a PPAR $\gamma$ agonist, has been described to inhibit AhR-induced cytochrome CYP1A1 enzyme activity and expression (Ciolino and Yeh 1999). Based on this, the next stage of our study was to check the impact of $1 \mu \mathrm{M}$ Les-2194, Les3640, Les-5935, or Les-6166 on expression of Cyp1a1, Cyp1b1, Cypla2, and Cyp2b10 mRNA in the 3T3-L1 cell line. In the experiments, $1 \mu \mathrm{M} \beta \mathrm{NF}$, i.e., a known agonist of the AhR receptor, was used as a positive control. The results showed that $\beta N F$ decreased the expression of $A h R$ receptor mRNA but increased the expression of the AhR-dependent genes Cyp1a1, Cyp1b1, and Cyp1a2. Unfortunately, no control; see supplementary material 2 for details. Data are expressed as means \pm SD of three independent experiments, each of which consisted of six replicates per treatment group. $* * P<0.01$ and $* * * P<0.001$ versus the control cells

expression of Cyp2b10 was detected in the experiments. As shown by literature data, the cyp2b10 expression in the $3 \mathrm{~T} 3$ cell line is very low and decreases during cell differentiation (Roth et al. 2008; Mesnier et al. 2015; Kong et al. 2018). Therefore, this may be the reason why we did not observe Cyp2b10 mRNA expression in the 3T3-L1 cell line.

They demonstrated that Les-2194 affected the expression of AhR, Cypla1, Cyp1b1, and Cypla2 mRNA in a similar way to $\beta N F$. However, Les-3640 increased only the Cypla1 mRNA expression, while Les-5935 decreased the mRNA expression of this enzyme. The Les-6166 compound decreased only the expression of $A h R$ receptor mRNA. It is important to underline that only $\beta N F$ and Les-2194 induced the expression of Cypla2 mRNA in the 3T3-L1 cell line.

Our previous study demonstrated that Les-2194 and Les3640 act in a PPAR $\gamma$-dependent way in SCC-15 cells and similar to known PPAR $\gamma$ agonists (rosiglitazone and 

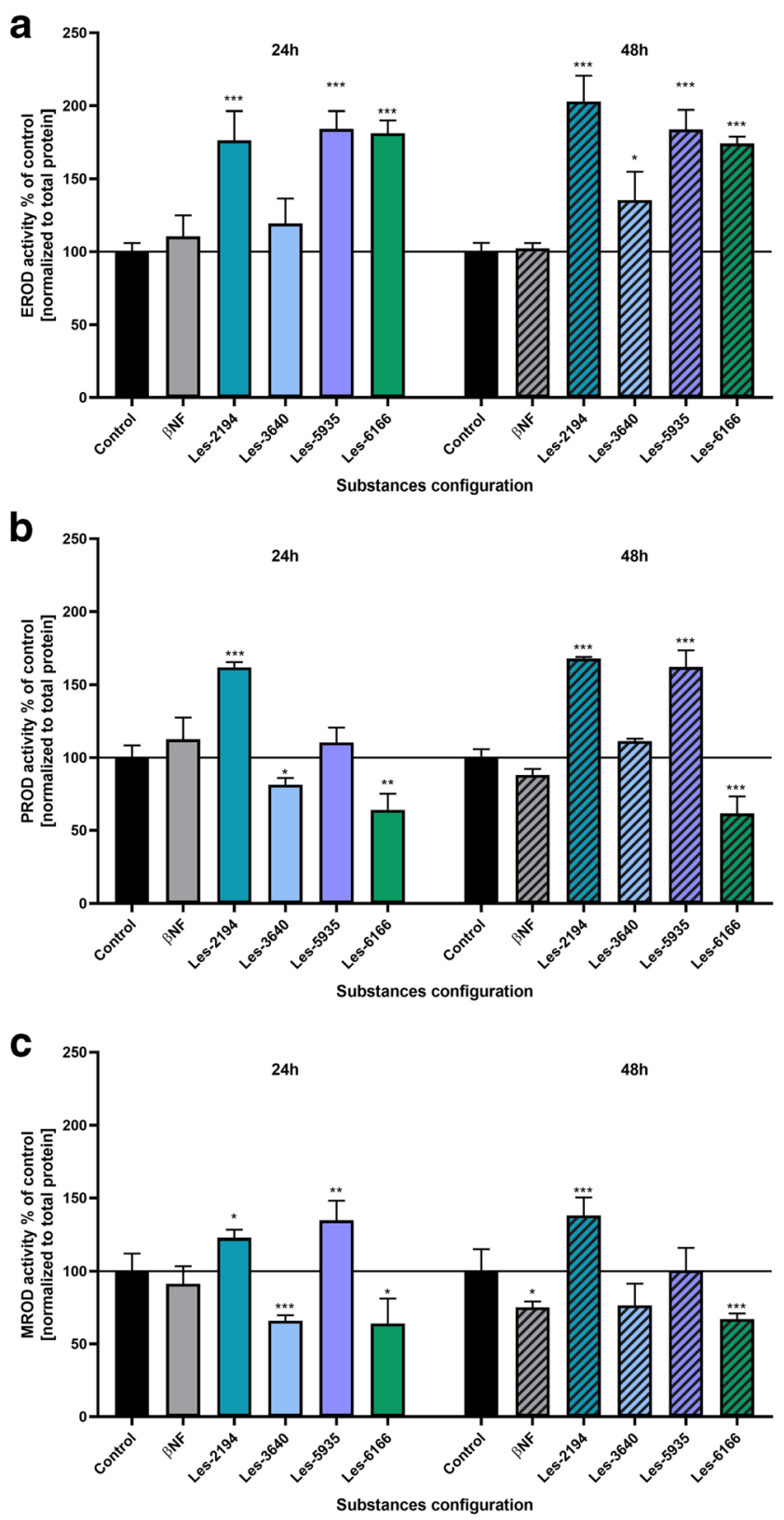

Fig. 5 Effect of $1 \mu \mathrm{M}$ Les-2194, Les-3640, Les-5935, or Les-6166 and $1 \mu \mathrm{M} \beta$-naphthoflavone ( $\beta \mathrm{NF}$ ) on EROD (a), MROD (b), and PROD (c) activities after 24 and $48 \mathrm{~h}$ of exposure of 3T3-L1 fibroblasts. Data are expressed as means \pm SD of three independent experiments, each of which consisted of six replicates per treatment group. $* * P<0.01$ and $* * * P<0.001$ versus the control cells

pioglitazone) (Szychowski et al. 2017a). Moreover, it was described that PPAR $\gamma$ agonists could activate the expression of CYP1A1 in mouse and human cells in vitro (Kim et al. 2008; Wójtowicz et al. 2017), which is probably possible due to the crosstalk of the PPAR $\gamma$ and AhR receptor pathways (Wójtowicz et al. 2017). Unfortunately, the data on the role of PPAR $\gamma$ agonists in the expression of CYP1A1, CYP1B1, or CYP2B1 mRNA (in mouse Cyp2b10) are very limited. However, since AhR control the expression of, e.g.,
CYP1A1, CYP1A2, and CYP1B1 (Beischlag et al. 2008), it can be assumed that PPAR $\gamma$ agonists should affect the expression of these genes as well.

On the other hand, it has been reported that the PPAR $\alpha$ agonist ciprofibrate can inhibit the expression of Cypla1 and Cyp1a2 mRNA and protein by interfering with AhR-dependent signaling in rat liver (Gallagher et al. 1995; Shaban et al. 2004). Such data suggest that Les-5935 and Les-6166 may be at least weak PPAR $\alpha$ agonists. The final part of our study was to evaluate the effect of Les-2194, Les-3640, Les-5935, or Les-6166 on the activity of Cyp1a1, Cyp1b1, Cyp1a2, and Cyp2b10 in the 3T3L1 cell line. It has been shown in various studies that EROD activities can be related to both CYP1A1 and CYP1A2 isoenzymes (Zamaratskaia and Zlabek 2009). However, some authors have suggested that the EROD assay measures CYP1B1 activity as well (Deeni et al. 2013). The MROD assay has been applied for measurement of the CYP1A2 activity (Conaway et al. 1996), whereas the PROD assay has been used to measure the CYP2B activity (Séide et al. 2016). Our data showed an increase in the EROD activity after 24 and $48 \mathrm{~h}$ in the 3T3-L1 cells exposed to $1 \mu \mathrm{M}$ Les-2194, Les-5935, or Les-6166; however, Les-3640 increased the EROD activity only after $48 \mathrm{~h}$. In the case of Les2194, the data on the Cyplal, Cypla1, and Cyplb1 mRNA expression and activity measured by the EROD assay are consistent. The increase in the EROD activity induced by Les-6166 may be explained by the increase in the Cyplal mRNA expression. Unfortunately, in the case Les-5935 and Les-3640, the increased EROD activity is not supported by the expression. This phenomenon may be a feedback effect where high enzyme activity inhibits its expression (Zanger and Schwab 2013).

Our data showed that only Les-2194 and Les-5935 increased the MROD activity, while $\beta$ NF, Les-3640, and Les6166 decreased the activity in the 3T3-L1 cells. To date, MROD activity has been correlated with CYP1A2 expression (Conaway et al. 1996). However, in our experiments, we observed increased expression of Cypla2 mRNA only after the treatment of the cells with Les-2194. It cannot be excluded that Les-5935 affects only the activity of Cyp1a2 without significant induction of mRNA expression.

Our data showed that Les-2194 and Les-5935 contributed to an increase in the PROD activity, while the Les-6266 compound decreased it at both time intervals. Interestingly, the experiments showed no expression of Cyp2b10 in 3T3-L1. A single $C Y P 2 B$ gene, i.e., $C Y P 2 B 6$, has been described in humans. In turn, mice have five $C y p 2 b$ genes: Cyp2b9, Cyp2b10, Cyp2b13, Cyp2b19, and Cyp2b23 (Nelson et al. 2004). In mice, the Cyp2b9, Cyp2b10, and Cyp2b13 forms are primarily expressed in the liver (Finger et al. 2011). The most important is Cyp2b10, and its expression is regulated by CAR (Honkakoski et al. 1998; Wang et al. 2003; Kretschmer and Baldwin 2005). Therefore, it cannot be excluded that the Les- compounds affect other than Cyp2b10 mRNA expression. 
Recently, it has been reported that different thiazolidinone derivatives exerted CYP inhibition activity in several isoforms (CYP1A2, CYP3A4, and CYP2C19) at $10 \mu \mathrm{M}$, but there was no CYP inhibition activity of CYP2C9 and CYP2D6 in human and rat liver microsomes (Ashraf et al. 2020). Unfortunately, the data on the CYP expression and/or activity after thiazolidinone treatment are limited.

It is well described that CYP1A1, CYP1A2, and CYP1B1 play an important role in the detoxication of environmental carcinogens and in the metabolic activation of dietary compounds with cancer preventive activity (Zanger and Schwab 2013; Alzahrani and Rajendran 2020). Moreover, the contribution of CYPs to cancer progression or prevention may depend on the balance of procarcinogen activation/detoxication and extrahepatic drug metabolism (Androutsopoulos et al. 2009). Similarly, CYP2B6 is involved in drug clearance (Zanger and Schwab 2013).

\section{Conclusions}

Our study is the first to explore the role of the Les-2194, Les3640, Les-5935, and Les-6166 compounds in the 3T3-L1 cell line. The experiments show that compounds Les-3640 and Les6166 at the 50 and $100 \mu \mathrm{M}$ concentrations activate caspase- 3 in 3T3-L1 cells and can be toxic in these concentrations. Moreover, the study has shown that only Les-2194 acts similarly to our positive control $\beta$ NF by affecting the mRNA expression of AhR, Cyp1a1, Cypla2, and Cyp1b1 in the 3T3-L1 cell line. Interestingly, both Les-2194 and Les-5935 increased the activity of EROD, MROD, and PROD. Given the important role of the AhR receptor in the detoxification system and its crosstalk with the PPAR $\gamma$ receptor, which is crucial in adipocyte differentiation, more research in this field is needed to explain the mechanism of the Les-2194, Les-3640, Les-5935, or Les-6166 action on drug metabolism or the detoxification system and adipocyte differentiation.

Supplementary Information The online version contains supplementary material available at https://doi.org/10.1007/s00210-020-02025-7.

Authors' contributions K.S. designed the research. A.K-L, D.K., and R.L. synthesized the compound used in the experiments. K.S., B.S., and J.G. performed the cell culture research. K.S. and R.L. analyzed the data and wrote the manuscript. J.G. obtained financial support for the project. All authors read and approved the manuscript. The authors declare that all data were generated in-house and that no paper mill was used.

Funding This work was supported by statutory funds from the University of Information Technology and Management in Rzeszow, Poland (DS 503-07-01-21)

\section{Compliance with ethical standards}

Conflict of interests The authors declare that they have no conflict of interests.
Open Access This article is licensed under a Creative Commons Attribution 4.0 International License, which permits use, sharing, adaptation, distribution and reproduction in any medium or format, as long as you give appropriate credit to the original author(s) and the source, provide a link to the Creative Commons licence, and indicate if changes were made. The images or other third party material in this article are included in the article's Creative Commons licence, unless indicated otherwise in a credit line to the material. If material is not included in the article's Creative Commons licence and your intended use is not permitted by statutory regulation or exceeds the permitted use, you will need to obtain permission directly from the copyright holder. To view a copy of this licence, visit http://creativecommons.org/licenses/by/4.0/.

\section{References}

Alzahrani AM, Rajendran P (2020) The multifarious link between cytochrome P450s and cancer. Oxidative Med Cell Longev 2020:1-18. https://doi.org/10.1155/2020/3028387

Androutsopoulos VP, Tsatsakis AM, Spandidos DA (2009) Cytochrome P450 CYP1A1: wider roles in cancer progression and prevention. BMC Cancer 9:187. https://doi.org/10.1186/1471-2407-9-187

Angus WG, Larsen MC, Jefcoate CR (1999) Expression of CYP1A1 and CYP1B1 depends on cell-specific factors in human breast cancer cell lines: role of estrogen receptor status. Carcinogenesis 20:947955

Asati V, Mahapatra DK, Bharti SK (2014) Thiazolidine-2,4-diones as multi-targeted scaffold in medicinal chemistry: potential anticancer agents. Eur J Med Chem 87:814-833. https://doi.org/10.1016/j. ejmech.2014.10.025

Ashraf S, Saeed A, Moon SH, Flörke U, Kim SH, Ashraf Z, Yaseen M, Latif M (2020) Design, synthesis and biological evaluation of 2(naphthoyl) iminothiazolidin-4-ones as potential anticancer agents. ChemistrySelect 5:3965-3970. https://doi.org/10.1002/slct. 202000579

Bardot O, Aldridge TC, Latruffe N, Green S (1993) PPAR-RXR heterodimer activates a peroxisome proliferator response element upstream of the bifunctional enzyme gene. Biochem Biophys Res Commun 192:37-45. https://doi.org/10.1006/bbrc.1993.1378

Barouki R (2013) Les xénobiotiques accumulés dans le tissu adipeux peuvent-ils contribuer à un risque carcinogène ? Ann Endocrinol (Paris) 74:154-155. https://doi.org/10.1016/j.ando.2013.03.022

Beischlag TV, Luis Morales J, Hollingshead BD, Perdew GH (2008) The aryl hydrocarbon receptor complex and the control of gene expression. Crit Rev Eukaryot Gene Expr 18:207-250. https://doi.org/10. 2964/jsik.kuni0223

Berger JP, Akiyama TE, Meinke PT (2005) PPARs: therapeutic targets for metabolic disease. Trends Pharmacol Sci 26:244-251. https:// doi.org/10.1016/j.tips.2005.03.003

Ciolino HP, Yeh GC (1999) Inhibition of aryl hydrocarbon-induced cytochrome P-450 1A1 enzyme activity and CYP1A1 expression by resveratrol. Mol Pharmacol 56:760-767

Conaway CC, Jiao D, Chung FL (1996) Inhibition of rat liver cytochrome P450 isozymes by isothiocyanates and their conjugates: a structureactivity relationship study. Carcinogenesis 17:2423-2427. https:// doi.org/10.1093/carcin/17.11.2423

Deeni YY, Ibbotson SH, Woods JA, Wolf CR, Smith G (2013) Cytochrome P450 CYP1B1 interacts with 8-methoxypsoralen (8MOP) and influences psoralen-ultraviolet A (PUVA) sensitivity. PLoS One 8:2-8. https://doi.org/10.1371/journal.pone.0075494

Di Bello D, Vaccaro E, Longo V et al (2007) Presence and inducibility by $\beta$-naphthoflavone of CYP1A1, CYP1B1 and phase II enzymes in 
Trematomus bernacchii, an Antarctic fish. Aquat Toxicol 84:19-26. https://doi.org/10.1016/j.aquatox.2007.05.010

Ellero S, Chakhtoura G, Barreau C, Langouët S, Benelli C, Penicaud L, Beaune P, de Waziers I (2010) Xenobiotic-metabolizing cytochromes P450 in human white adipose tissue: expression and induction. Drug Metab Dispos 38:679-686. https://doi.org/10.1124/dmd. 109.029249

Finger JH, Smith CM, Hayamizu TF, McCright IJ, Eppig JT, Kadin JA, Richardson JE, Ringwald M (2011) The mouse gene expression database (GXD): 2011 update. Nucleic Acids Res 39:835-841. https://doi.org/10.1093/nar/gkq1132

Gallagher EP, Buetler TM, Stapleton PL, Wang CH, Stahl DL, Eaton DL (1995) The effects of diquat and ciprofibrate on mRNA expression and catalytic activities of hepatic xenobiotic metabolizing and antioxidant enzymes in rat liver. Toxicol Appl Pharmacol 134:81-91. https://doi.org/10.1006/taap.1995.1171

Havrylyuk D, Zimenkovsky B, Vasylenko O, Gzella A, Lesyk R (2012) Synthesis of new 4-thiazolidinone-, pyrazoline-, and isatin-based conjugates with promising antitumor activity. J Med Chem 55: 8630-8641. https://doi.org/10.1021/jm300789g

He Q, Huang C, Zhao L, Feng J, Shi Q, Wang D, Wang S (2013) $\alpha$ Naphthoflavone inhibits 3T3-L1 pre-adipocytes differentiation via modulating p38MAPK signaling. Int J Clin Exp Pathol 6:168-178

Hessel-Pras S, Ehlers A, Braeuning A, Lampen A (2018) The aryl hydrocarbon receptor and retinoid receptors cross-talk at the Cyp1A1 promoter in vitro. EXCLI J 17:246-256. https://doi.org/10.17179/ excli2018-1147

Honkakoski P, Zelko I, Sueyoshi T, Negishi M (1998) The nuclear orphan receptor CAR-retinoid $\mathrm{X}$ receptor heterodimer activates the phenobarbital-responsive enhancer module of the CYP2B gene. Mol Cell Biol 18:5652-5658. https://doi.org/10.1128/mcb.18.10. 5652

Jackson E, Shoemaker R, Larian N, Cassis L (2017) Adipose tissue as a site of toxin accumulation. Compr Physiol 7:1085-1135. https://doi. org/10.1002/cphy.c160038

Kaminskyy D, Kryshchyshyn A, Lesyk R (2017a) 5-Ene-4thiazolidinones - an efficient tool in medicinal chemistry. Eur J Med Chem 140:542-594. https://doi.org/10.1016/j.ejmech.2017. 09.031

Kaminskyy D, Kryshchyshyn A, Lesyk R (2017b) Recent developments with rhodanine as a scaffold for drug discovery. Expert Opin Drug Discovery 12:1233-1252. https://doi.org/10.1080/17460441.2017. 1388370

Kennedy SW, Lorenzen A, James CA, Collins BT (1993) Ethoxyresorufin-O-deethylase and porphyrin analysis in chicken embryo hepatocyte cultures with a fluorescence multiwell plate reader. Anal Biochem 211:102-112. https://doi.org/10.1006/abio. 1993.1239

Kim HG, Han EH, Jeong HG (2008) Effect of troglitazone on CYP1A1 induction. Toxicology 246:166-171. https://doi.org/10.1016/j.tox. 2008.01.003

Kong X, Yao T, Zhou P, et al (2018) Brown adipose tissue controls skeletal muscle function via the secretion of myostatin. Cell Metab 28:631-643.e3. doi: https://doi.org/10.1016/j.cmet.2018.07.004

Kretschmer XC, Baldwin WS (2005) CAR and PXR: Xenosensors of endocrine disrupters? Chem Biol Interact 155:111-128. https://doi. org/10.1016/j.cbi.2005.06.003

Kryshchyshyn A, Atamanyuk D, Lesyk R (2012) Fused thiopyrano[2,3d]thiazole derivatives as potential anticancer agents. Sci Pharm 80: 509-529. https://doi.org/10.3797/scipharm.1204-02

Kryshchyshyn A, Roman O, Lozynskyi A, Lesyk R (2018) Thiopyrano[2,3-d]thiazoles as new efficient scaffolds in medicinal chemistry. Sci Pharm 86:26. https://doi.org/10.3390/ scipharm86020026
Lea MA, Sura M, Desbordes C (2004) Inhibition of cell proliferation by potential peroxisome proliferator-activated receptor (PPAR) gamma agonists and antagonists. Anticancer Res 24:2765-2771

Lesyk R (2020a) Drug design: 4-thiazolidinones applications. Part 1. Synthetic routes to the drug-like molecules. J Med Sci 89:e406. doi: $10.20883 /$ medical.406

Lesyk R (2020b) Drug design: 4-thiazolidinones applications. Part 2. Pharmacological profiles. J Med Sci e407.

Li F, Zhu W, Gonzalez FJ (2017) Potential role of CYP1B1 in the development and treatment of metabolic diseases. Pharmacol Ther 178: 18-30. https://doi.org/10.1016/j.pharmthera.2017.03.007

Lu W, Che P, Zhang Y, Li H, Zou S, Zhu J, Deng J, Shen X, Jiang H, Li J, Huang J (2011) HL005 - a new selective PPAR $\gamma$ antagonist specifically inhibits the proliferation of MCF-7. J Steroid Biochem Mol Biol 124:112-120. https://doi.org/10.1016/j.jsbmb.2011.01.019

Malik KU, Jennings BL, Yaghini FA, Sahan-Firat S, Song CY, Estes AM, Fang XR (2012) Contribution of cytochrome P450 1B1 to hypertension and associated pathophysiology: a novel target for antihypertensive agents. Prostaglandins Other Lipid Mediat 98:69-74. https://doi.org/10.1016/j.prostaglandins.2011.12.003

Mesnier A, Champion S, Louis L, Sauzet C, May P, Portugal H, Benbrahim K, Abraldes J, Alessi MC, Amiot-Carlin MJ, Peiretti F, Piccerelle P, Nalbone G, Villard PH (2015) The transcriptional effects of PCB118 and PCB153 on the liver, adipose tissue, muscle and colon of mice: highlighting of Glut4 and Lipin1 as main target genes for PCB induced metabolic disorders. PLoS One 10:0-17. doi: https://doi.org/10.1371/journal.pone.0128847, e0128847

Nebert DW, Dalton TP (2006) The role of cytochrome P450 enzymes in endogenous signalling pathways and environmental carcinogenesis. Nat Rev Cancer 6:947-960. https://doi.org/10.1038/nrc2015

Nebert DW, Roe AL, Dieter MZ, Solis WA, Yang Y, Dalton TP (2000) Role of the aromatic hydrocarbon receptor and $[\mathrm{Ah}]$ gene battery in the oxidative stress response, cell cycle control, and apoptosis. Biochem Pharmacol 59:65-85. https://doi.org/10.1016/S00062952(99)00310-X

Nelson DR, Zeldin DC, Hoffman SMG, Maltais LJ, Wain HM, Nebert DW (2004) Comparison of cytochrome P450 (CYP) genes from the mouse and human genomes, including nomenclature recommendations for genes, pseudogenes and alternative-splice variants. Pharmacogenetics 14:1-18. https://doi.org/10.1097/01.fpc. 0000054151.92680 .31

Nicholson DW, Ali A, Thornberry NA, Vaillancourt JP, Ding CK, Gallant M, Gareau Y, Griffin PR, Labelle M, Lazebnik YA, Munday NA, Raju SM, Smulson ME, Yamin TT, Yu VL, Miller DK (1995) Identification and inhibition of the ICE/CED-3 protease necessary for mammalian apoptosis. Nature 376:37-43. https://doi. org/10.1038/376037a0

Perl K, Ushakov K, Pozniak Y, Yizhar-Barnea O, Bhonker Y, Shivatzki S, Geiger T, Avraham KB, Shamir R (2017) Reduced changes in protein compared to mRNA levels across non-proliferating tissues. BMC Genomics 18:305. https://doi. org/10.1186/s12864-017-3683-9

Rampersad SN (2012) Multiple applications of Alamar Blue as an indicator of metabolic function and cellular health in cell viability bioassays. Sensors 12:12347-12360. https://doi.org/10.3390/ s120912347

Roth A, Looser R, Kaufmann M, Blättler SM, Rencurel F, Huang W, Moore DD, Meyer UA (2008) Regulatory cross-talk between drug metabolism and lipid homeostasis: constitutive androstane receptor and pregnane $\mathrm{X}$ receptor increase Insig-1 expression. Mol Pharmacol 73:1282-1289. https://doi.org/10.1124/mol.107.041012

Scatena R, Bottoni P, Giardina B (2008) Mitochondria, PPARs, and cancer: is receptor-independent action of PPAR agonists a key? PPAR Res 2008:1-10. https://doi.org/10.1155/2008/256251 
Séïde M, Marion M, Mateescu MA, Averill-Bates DA (2016) The fungicide thiabendazole causes apoptosis in rat hepatocytes. Toxicol in Vitro 32:232-239. https://doi.org/10.1016/j.tiv.2015.12.018

Shaban Z, El-Shazly S, Ishizuka M et al (2004) PPARgamma-dependent modulation of hepatic CYP1A by clofibric acid in rats. Arch Toxicol 78. https://doi.org/10.1007/s00204-004-0569-9

Shoemaker RH (2006) The NCI60 human tumour cell line anticancer drug screen. Nat Rev Cancer 6:813-823. https://doi.org/10.1038/ nrc1951

Song CY, Ghafoor K, Ghafoor HU, Khan NS, Thirunavukkarasu S, Jennings BL, Estes AM, Zaidi S, Bridges D, Tso P, Gonzalez FJ, Malik KU (2016) Cytochrome P450 1B1 contributes to the development of atherosclerosis and hypertension in apolipoprotein Edeficient mice. Hypertension 67:206-213. https://doi.org/10.1161/ HYPERTENSIONAHA.115.06427

Spink DC, Spink BC, Cao JQ et al (1998) Differential expression of CYP1A1 and CYP1B1 in human breast epithelial cells and breast tumor cells. Carcinogenesis 19:291-298. https://doi.org/10.1093/ carcin/19.2.291

Szychowski KA, Leja ML, Kaminskyy DV, Kryshchyshyn AP, Binduga UE, Pinyazhko OR, Lesyk RB, Tobiasz J, Gmiński J (2017a) Anticancer properties of 4-thiazolidinone derivatives depend on peroxisome proliferator-activated receptor gamma (PPAR $\gamma$ ). Eur J Med Chem 141:162-168. https://doi.org/10.1016/j.ejmech.2017. 09.071

Szychowski KA, Leja ML, Kaminskyy DV, Binduga UE, Pinyazhko OR, Lesyk RB, Gmiński J (2017b) Study of novel anticancer 4thiazolidinone derivatives. Chem Biol Interact 262:46-56. https:// doi.org/10.1016/j.cbi.2016.12.008

Szychowski KA, Kaminskyy DV, Leja ML, Kryshchyshyn AP, Lesyk RB, Tobiasz J, Wnuk M, Pomianek T, Gmiński J (2019) Anticancer properties of 5Z-(4-fluorobenzylidene)-2-(4-hydroxyphenylamino)thiazol-4-one. Sci Rep 9:10609. https://doi.org/10.1038/s41598$019-47177-6$

Tachibana K, Yamasaki D, Ishimoto K, Doi T (2008) The role of PPARs in cancer. PPAR Res 2008:1-15. https://doi.org/10.1155/2008/ 102737

Tian J, Feng Y, Fu H, Xie HQ, Jiang JX, Zhao B (2015) The aryl hydrocarbon receptor: a key bridging molecule of external and internal chemical signals. Environ Sci Technol 49:9518-9531. https://doi. org/10.1021/acs.est.5b00385
Tripathi AC, Gupta SJ, Fatima GN, et al (2014) 4-Thiazolidinones: the advances continue.... Eur J Med Chem 72:52-77. https://doi.org/10. 1016/j.ejmech.2013.11.017

Wang H, Faucette S, Sueyoshi T, Moore R, Ferguson S, Negishi M, LeCluyse EL (2003) A novel distal enhancer module regulated by pregnane $\mathrm{X}$ receptor/constitutive androstane receptor is essential for the maximal induction of CYP2B6 gene expression. J Biol Chem 278:14146-14152. https://doi.org/10.1074/jbc.M212482200

Wojtowicz AK, Szychowski KA, Kajta M (2014) PPAR- $\gamma$ agonist GW1929 but not antagonist GW9662 reduces TBBPA-induced neurotoxicity in primary neocortical cells. Neurotox Res 25:311-322. https://doi.org/10.1007/s12640-013-9434-z

Wójtowicz AK, Szychowski KA, Wnuk A, Kajta M (2017) Dibutyl phthalate (DBP)-induced apoptosis and neurotoxicity are mediated via the aryl hydrocarbon receptor (AhR) but not by estrogen receptor alpha $(E R \alpha)$, estrogen receptor beta $(E R \beta)$, or peroxisome proliferator-activated receptor gamma (PPAR $\gamma)$ in mouse $\mathrm{C}$. Neurotox Res 31:77-89. https://doi.org/10.1007/s12640-016-9665$\mathrm{x}$

Wright MB, Bortolini M, Tadayyon M, Bopst M (2014) Minireview: challenges and opportunities in development of PPAR agonists. Mol Endocrinol 28:1756-1768. https://doi.org/10.1210/me.20131427

Zamaratskaia G, Zlabek V (2009) EROD and MROD as markers of cytochrome P450 1A activities in hepatic microsomes from entire and castrated male pigs. Sensors 9:2134-2147. https://doi.org/10. $3390 / \mathrm{s} 90302134$

Zanger UM, Schwab M (2013) Cytochrome P450 enzymes in drug metabolism: regulation of gene expression, enzyme activities, and impact of genetic variation. Pharmacol Ther 138:103-141. https://doi. org/10.1016/j.pharmthera.2012.12.007

Zhou L, Zhong Y, Xue MZ, Kuang D, Cao XW, Zhao ZJ, Li HL, Xu YF, Wang R (2015) Design, synthesis and evaluation of PPAR gamma binding activity of 2-thioxo-4-thiazolidinone derivatives. Chin Chem Lett 26:63-68. https://doi.org/10.1016/j.cclet.2014.10.008

Publisher's note Springer Nature remains neutral with regard to jurisdictional claims in published maps and institutional affiliations. 